\title{
Modeling and Detection of Ice Particle Accretion in Aircraft Engine Compression Systems
}

Ryan D. May

Vantage Partners, LLC, Brook Park, Ohio

Donald L. Simon and Ten-Huei Guo

Glenn Research Center, Cleveland, Ohio 


\section{NASA STI Program . . . in Profile}

Since its founding, NASA has been dedicated to the advancement of aeronautics and space science. The NASA Scientific and Technical Information (STI) program plays a key part in helping NASA maintain this important role.

The NASA STI Program operates under the auspices of the Agency Chief Information Officer. It collects, organizes, provides for archiving, and disseminates NASA's STI. The NASA STI program provides access to the NASA Aeronautics and Space Database and its public interface, the NASA Technical Reports Server, thus providing one of the largest collections of aeronautical and space science STI in the world. Results are published in both non-NASA channels and by NASA in the NASA STI Report Series, which includes the following report types:

- TECHNICAL PUBLICATION. Reports of completed research or a major significant phase of research that present the results of NASA programs and include extensive data or theoretical analysis. Includes compilations of significant scientific and technical data and information deemed to be of continuing reference value. NASA counterpart of peer-reviewed formal professional papers but has less stringent limitations on manuscript length and extent of graphic presentations.

- TECHNICAL MEMORANDUM. Scientific and technical findings that are preliminary or of specialized interest, e.g., quick release reports, working papers, and bibliographies that contain minimal annotation. Does not contain extensive analysis.

- CONTRACTOR REPORT. Scientific and technical findings by NASA-sponsored contractors and grantees.
- CONFERENCE PUBLICATION. Collected papers from scientific and technical conferences, symposia, seminars, or other meetings sponsored or cosponsored by NASA.

- SPECIAL PUBLICATION. Scientific, technical, or historical information from NASA programs, projects, and missions, often concerned with subjects having substantial public interest.

- TECHNICAL TRANSLATION. Englishlanguage translations of foreign scientific and technical material pertinent to NASA's mission.

Specialized services also include creating custom thesauri, building customized databases, organizing and publishing research results.

For more information about the NASA STI program, see the following:

- Access the NASA STI program home page at http://www.sti.nasa.gov

- E-mail your question to help@sti.nasa.gov

- Fax your question to the NASA STI Information Desk at 443-757-5803

- Phone the NASA STI Information Desk at 443-757-5802

- Write to: STI Information Desk NASA Center for AeroSpace Information 7115 Standard Drive Hanover, MD 21076-1320 
NASA/TM-2012-217742

AIAA-2012-4649

\section{Modeling and Detection of Ice Particle Accretion in Aircraft Engine Compression Systems}

Ryan D. May

Vantage Partners, LLC, Brook Park, Ohio

Donald L. Simon and Ten-Huei Guo

Glenn Research Center, Cleveland, Ohio

Prepared for the

Atmospheric Flight Mechanics Conference

sponsored by the American Institute of Aeronautics and Astronautics

Minneapolis, Minnesota, August 13-16, 2012

National Aeronautics and

Space Administration

Glenn Research Center

Cleveland, Ohio 44135 


\section{Acknowledgments}

The authors would like to thank Joe Veres of NASA Glenn Research Center for generating the data used to create the Low Pressure Compressor (LPC) iced compressor maps. Additional thanks go to Sanjay Garg and James Heidmann of the NASA Glenn Research Center for their support, and the Aviation Safety Program's Vehicle Systems Safety Technologies program for funding this research.

Level of Review: This material has been technically reviewed by technical management.

Available from

NASA Center for Aerospace Information 7115 Standard Drive

Hanover, MD 21076-1320
National Technical Information Service 5301 Shawnee Road Alexandria, VA 22312

Available electronically at http://www.sti.nasa.gov 


\title{
Modeling and Detection of Ice Particle Accretion in Aircraft Engine Compression Systems
}

\author{
Ryan D. May \\ Vantage Partners, LLC \\ Brook Park, Ohio 44142 \\ Donald L. Simon and Ten-Huei Guo \\ National Aeronautics and Space Administration \\ Glenn Research Center \\ Cleveland, Ohio 44135
}

\begin{abstract}
The accretion of ice particles in the core of commercial aircraft engines has been an ongoing aviation safety challenge. While no accidents have resulted from this phenomenon to date, numerous engine power loss events ranging from uneventful recoveries to forced landings have been recorded. As a first step to enabling mitigation strategies during ice accretion, a detection scheme must be developed that is capable of being implemented on board modern engines. In this paper, a simple detection scheme is developed and tested using a realistic engine simulation with approximate ice accretion models based on data from a compressor design tool. These accretion models are implemented as modified Low Pressure Compressor maps and have the capability to shift engine performance based on a specified level of ice blockage. Based on results from this model, it is possible to detect the accretion of ice in the engine core by observing shifts in the typical sensed engine outputs. Results are presented in which, for a 0.1 percent false positive rate, a true positive detection rate of 98 percent is achieved.
\end{abstract}

\section{Nomenclature}

$\begin{array}{ll}\text { C-MAPSS40k } & \text { the Commercial Modular Aero-Propulsion System Simulation 40k } \\ \text { EPR } & \text { Engine Pressure Ratio }\left(P_{50} / P_{2}\right) \\ \text { HIWC } & \text { High Ice Water Content } \\ \text { HPC } & \text { High Pressure Compressor } \\ \text { HPT } & \text { High Pressure Turbine } \\ \text { ISA } & \text { International Standard Atmosphere } \\ \text { LPC } & \text { Low Pressure Compressor } \\ \text { LPT } & \text { Low Pressure Turbine } \\ N_{c} & \text { Core shaft speed (rpm) } \\ N_{f} & \text { Fan shaft speed (rpm) } \\ \text { PLA } & \text { Power Lever Angle }(\text { deg) } \\ P_{X} & \text { Pressure at station } X(\mathrm{psig}) \\ P_{s X} & \text { Static pressure at station } X \text { (psig) } \\ T_{X} & \text { Temperature at station } X \text { (deg Rankine) } \\ W_{f} & \text { fuel mass-flow rate }\left(\mathrm{lb}_{\mathrm{m}} / \mathrm{s}\right) \\ X_{c 2} & \text { Sensor value } X \text { corrected to inlet conditions }\end{array}$




\section{Introduction}

Over the past twenty years, there have been over 200 reported cases of aircraft engine power loss due to the accretion of ice crystal particles in the compression system of commercial turbofan engines (Ref. 1). The majority of the work in response to this aviation safety concern has focused on understanding the mechanism by which particles in high ice-water content (HIWC) conditions can accrete on compressor stator blades, understanding the environmental conditions in which accretion can occur, and related regulatory guidance. While avoidance of HIWC conditions and compressor redesigns are the ideal long-term solutions, it is important to provide some mechanism for existing aircraft to safely operate in these conditions if they are encountered.

Unfortunately, existing airframe sensors and manual monitoring approaches are not capable of detecting these HIWC conditions: typical weather RADAR sees the condition as clear air, and there is no visible indication of ice growth on the cockpit windows (Ref. 2). The total air temperature probe anomaly (Ref. 3) has been found to be correlated with the HIWC conditions, but it is not a reliable indicator as only some of the probes on planes that have experienced power loss showed the anomaly (Ref. 2). While new sensors are in development and show much promise (Ref. 4), previous work has shown that it may be possible to detect icing by monitoring the performance of the engines (Ref. 5).

If a system is capable of detecting the presence of ice blockage, it may be possible to change the engine's operating point to actively mitigate the impact of that ice. Earlier detection of the presence of ice blockage leads to a larger number of feasible mitigation strategies. For example, if a thin layer of accreted ice is detected it may be possible to increase the compressor's speed to shed the ice. However, it is likely that ice shedding from the compressor through the rest of the engine core can cause compressor surge, flameout, and engine damage (Ref. 6). It is reasonable to assume that the larger the ice blockage is when it is shed, the more serious the consequences. Additional possible mitigation techniques include modifying engine bleeds and variable stator vanes to increase the flow through the core, or increasing the compressor temperature, reducing the chance of accretion.

From a propulsion system perspective, accreted ice restricts compressor flow capacity and reduces compressor efficiency (Ref. 7). These changes can be modeled as a shift in the compressor map. A compressor map (shown in Fig. 1) captures the operational behavior of a compression system by relating the mass flow rate through the compressor to the pressure ratio across the compressor at given rotational speeds. In addition to these speed lines, a compressor map contains a surge line. This surge line represents the collection of points beyond which it is not possible for the compressor to operate. If one attempts to operate the compressor beyond the surge line, flow reversal will typically occur resulting in loss of thrust and potential component damage.

Previous simulations conducted using icing code (LEWICE) and steady-state compressor design code (COMDES) determined that for a generic $40,000 \mathrm{lb}_{\mathrm{f}}$ thrust class engine, it is possible for ice to accrete in the second stator row of the Low Pressure Compressor (LPC) (Ref. 7). Based on this information, new compressor maps were developed that capture the effect of fixed levels of ice blockage (10, 20, 27, 30, 35, and 40 percent). All of the maps are shown in Figure 1. It is clear that for each speed line there is a decrease in mass flow rate and pressure ratio as the size of ice blockage increases. This is particularly true at higher rotational speeds. In addition, the surge line moves to lower pressure ratios as the ice blockage increases. This means that the compressor is likely operating very close to surge during icing conditions.

The work described in this paper seeks to develop a detection algorithm using the existing sensor suite that can be realistically implemented in modern commercial aircraft gas turbine engines. To develop this algorithm, engine icing models will be implemented in a high-fidelity engine simulation through the discussed "iced" LPC compressor maps. This will enable a study of the impact of ice accretion on the output of the available sensors. Once the algorithm is developed, it will be tested in both iced and noniced conditions and various operating points to determine the detection accuracy and latency. 


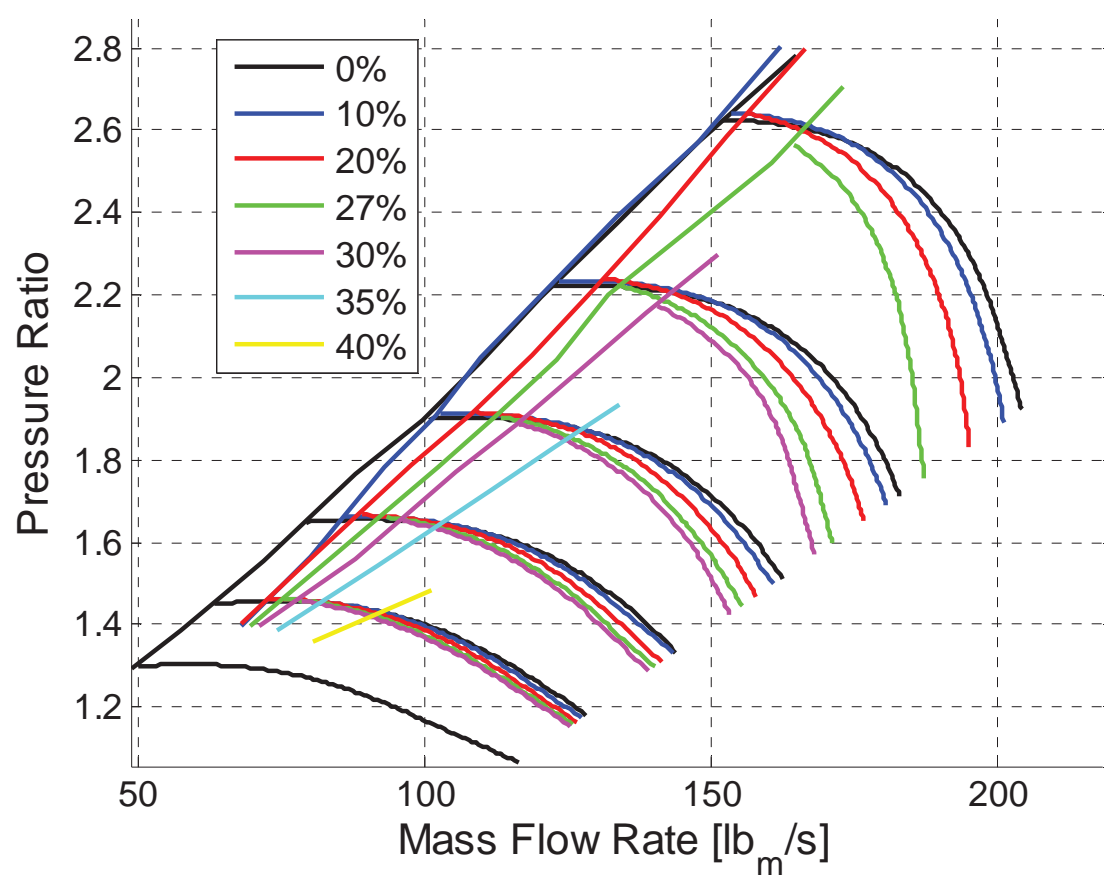

Figure 1.-Low pressure compressor maps for various levels of ice blockage (nominal (0 percent), 10, 20, 27, 30, 35, and 40 percent) in the second LPC stator row. Data to construct these maps were taken from Reference 5.

The engine simulation environment and means of simulating the effect of ice accretion in the LPC are discussed in Section II. Section III contains an analysis of the change in engine sensor outputs as the ice blockage grows larger. Section IV presents a practical detection algorithm with the results shown in Section V. Some conclusions and future work are discussed in Section VI.

\section{Modeling Engine Icing}

In order to simulate the effect of ice accretion on engine operation, LPC maps with various levels of ice blockage are integrated into a high-fidelity engine simulation. The aircraft engine simulation used in this work is the NASA Commercial Modular Aero-Propulsion System Simulation 40k (C-MAPSS40k). This simulation models a commercial, high-bypass, turbofan engine in the $40,000 \mathrm{lb}_{\mathrm{f}}$ thrust class (Ref. 8). The model is a 0-dimensional, physics-based simulation written in MATLAB/Simulink (The Mathworks, Inc.), and is capable of full envelope operation. Further, the simulation includes a controller with an "industry standard" architecture (Refs. 9 and 10) that can be used as a baseline against which to compare the performance of new control laws. The presence of a realistic controller is crucial since the engine controller will naturally respond to the presence of the ice blockage, thus changing the operating point. In fact, it has been shown that this action may lead to the engine rollback phenomenon observed in some of the icing induced power-loss events (Ref. 5). Another key component of C-MAPSS40k is the ability to enable realistic sensor noise. This noise is not a Gaussian noise summed to the sensor output; rather it is based on work introduced in Reference 11, and is present on all sensors including those used for control. The resulting noise appears similar to that of a random walk process.

Once the compressor maps are encoded in the proper format, they are integrated into C-MAPSS40k. The code that models the LPC component is passed a variable containing the ice blockage percentage (between 0 and 40 percent). In order to simulate ice blockage at levels between the fixed points, the operating point is computed on each iced map and then linear interpolation is used to compute the actual operating point. 
Throughout the paper, ice blockages greater than 27 percent will not be studied for the following reasons. If the detection scheme has not identified the icing prior to this point it will likely be too late to implement most mitigation strategies. Furthermore, the impact of icing on the engine becomes highly non-linear at this point and the LPC will be choked for nearly all operating points.

\section{Impact of Icing on Sensed Outputs}

The purpose of the engine control law is to take the throttle angle (PLA) commanded by the pilot and regulate the fuel flow rate to the engine to maintain a desired level of thrust in a safe manner. Since thrust is not a measurable quantity, either fan speed $\left(N_{f}\right)$ or engine pressure ratio (EPR, which is the ratio of LPT exit pressure to inlet pressure) is regulated, both of which are proportional to thrust. While engine control is more complex than this simple regulation scheme (see Refs. 9 and 10 for more details), it is sufficient for this work to understand that the response of the engine to icing will be different depending on which variable is regulated.

The typical commercial aircraft engine contains between seven and ten sensors used for control and monitoring purposes. Most engines contain sensors consisting of inlet pressure and temperature $\left(P_{2}\right.$ and $\left.T_{2}\right)$, fuel flow $\left(W_{f}\right)$, fan and core speed $\left(N_{f}\right.$ and $\left.N_{c}\right)$, burner pressure $\left(P_{s 3}\right)$ and exhaust gas temperature $\left(T_{50}\right)$. Engines that are EPR controlled have a LPT exit pressure $\left(P_{50}\right)$ sensor. Additionally, many engines are equipped with inter-compressor pressure and temperature $\left(P_{25}\right.$ and $\left.T_{25}\right)$ sensors for gas path monitoring. The engine schematic shown in Figure 2 highlights the location of these sensors.

In the following example, the outputs of the ten engine sensors included in the C-MAPSS40k engine simulation are shown for a condition in which there is initially no ice in the LPC, but at $10 \mathrm{~s}$ ice begins to accrete until $20 \mathrm{~s}$, at which point there is 27 percent ice blockage. The simulation is performed for both EPR and fan speed controlled engines to generate the plots shown in Figure 3. One can see that the inlet conditions $\left(P_{2}\right.$ and $\left.T_{2}\right)$ are identical since both tests were conducted at the same flight condition. As expected, $N_{f}$ is nearly constant for the fan speed controlled engine as is $P_{50}$ for the EPR controlled engine. The six remaining sensors all exhibit common behavior during ice accretion. Further, the magnitude of the change is nearly the same in all but $W_{f}$ and $P_{s 3}$ where the change is much smaller for fan speed controlled and EPR controlled engines, respectively. Based on this information, any detection algorithm that seeks to operate under both EPR and fan speed control should focus on $N_{c}, T_{25}, T_{50}$, and $P_{25}$.

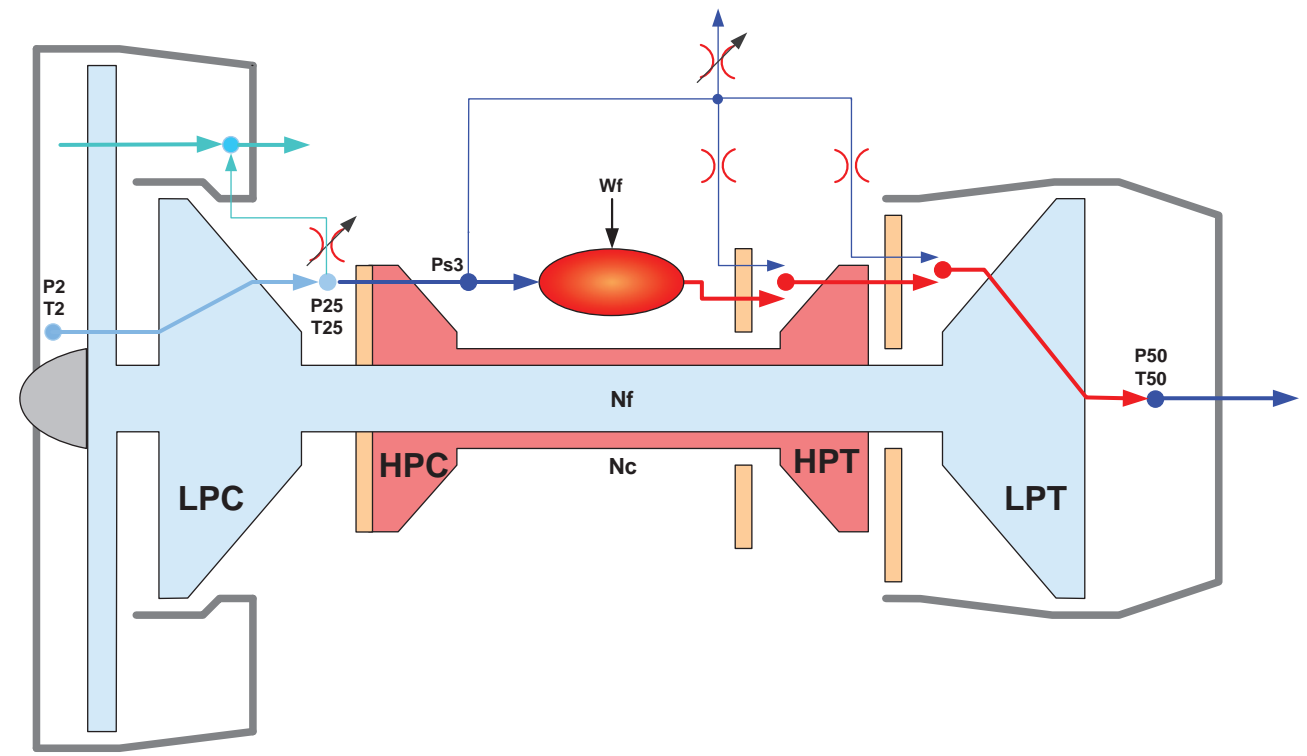

Figure 2.- Schematic of a typical twin-spool, high-bypass commercial aircraft engine. Reproduced from Reference 8. 

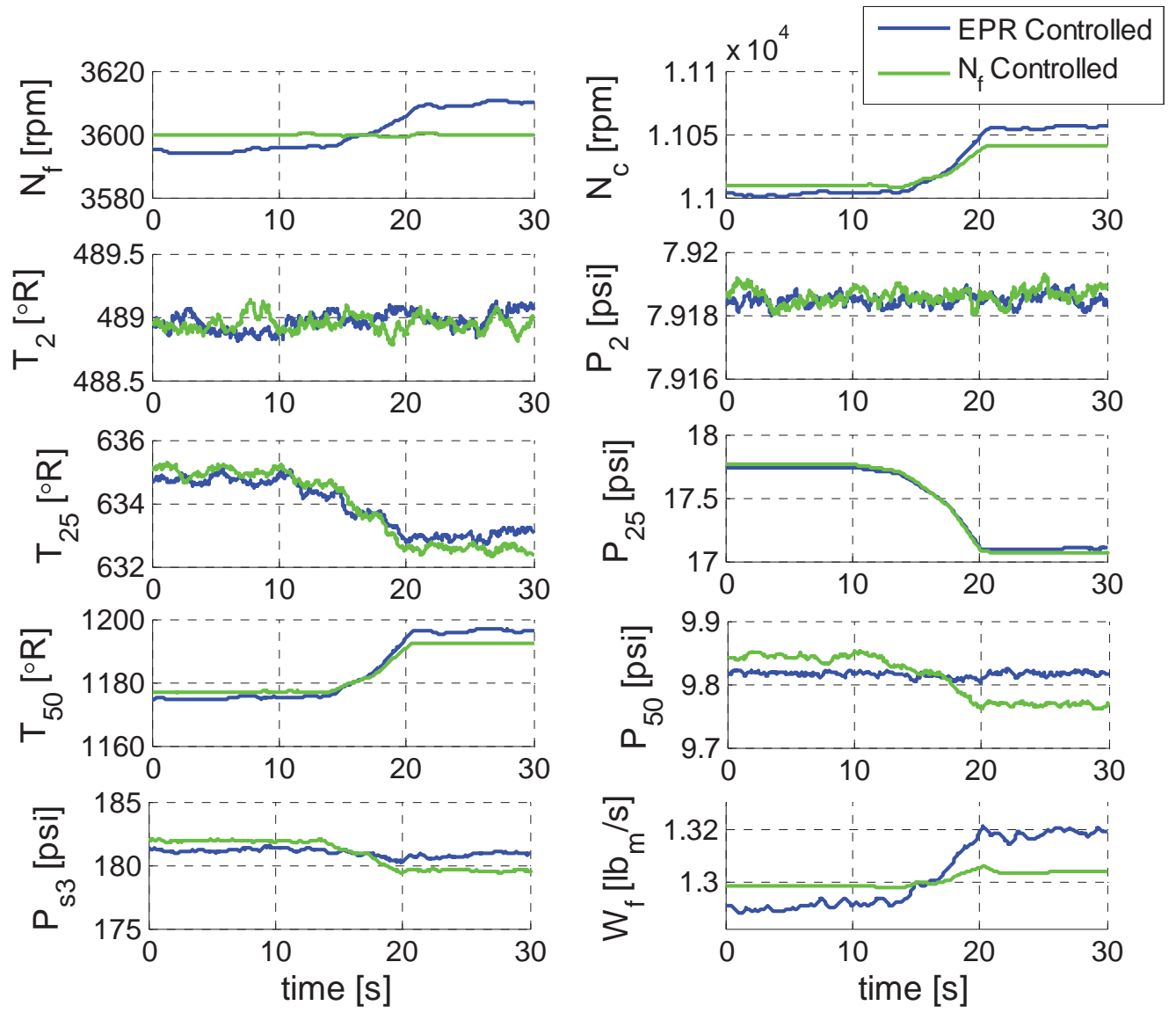

Figure 3.-Sensor outputs for EPR controlled and fan speed controlled engines at 25,000 ft, Mach 0.6, ISA+10, PLA of $68^{\circ}$. Ice accretion begins at $10 \mathrm{~s}$ and ends at 27 percent blockage at $20 \mathrm{~s}$.

However, as stated earlier, the station 25 sensors are not present in all engines. Thus it makes sense to consider EPR and fan speed controlled engines separately. When EPR controlled, $N_{f}$ and $W_{f}$ are useful, and when fan speed controlled, $P_{50}$ and $P_{s 3}$ are useful. The simulations throughout the remainder of this paper will utilize an EPR setpoint controller.

There are many different types of detection schemes ranging from simple threshold techniques to sophisticated adaptive, model-based approaches. However, more complex designs present increased certification challenges and also require more processing resources. Thus, the authors seek to develop as simple an approach as possible to mitigate some of these implementation challenges and enable earlier acceptance and adoption of this approach.

The original intent was to develop a detection scheme where expected sensor measurement values as a function of flight condition are stored in a lookup table or database. The difference between the actual sensor measurements and the typical values is calculated. The resulting vector of data, known as a residual vector, describes how far each sensor's output is from the expected. This vector can then be operated on to generate a scalar "distance" performance metric. When the distance exceeds a specified threshold, the fault is detected. 
To study the validity of this approach, nominal sensor outputs are recorded at a flight condition of 25,000 ft, Mach 0.6, ISA, and a PLA of $68^{\circ}$, for a mid-life (50 percent deteriorated) engine. Three variations were then evaluated:

1. Ice accretion from 0 to 27 percent occurs between 10 and $20 \mathrm{~s}$ at the trim flight condition in a mid-life engine

2. No ice accretion at the trim flight condition but with an end-of-life (100 percent deteriorated) engine

3. No ice accretion at a flight condition of $25,100 \mathrm{ft}$, Mach 0.62 , ISA $+10^{\circ}$, PLA of $68^{\circ}$ with an end-oflife engine.

The residuals for each case are computed and plotted in Figure 4. The flight condition for Case 3 was chosen to be slightly shifted from the trim point in order to evaluate the impact of changes in operating point on the ability to detect the presence of icing. Ideally for detection, one would find that the residuals from the "icing" event are larger than those corresponding to other variations (such as engine deterioration or flight condition). Unfortunately, that is not the case here.
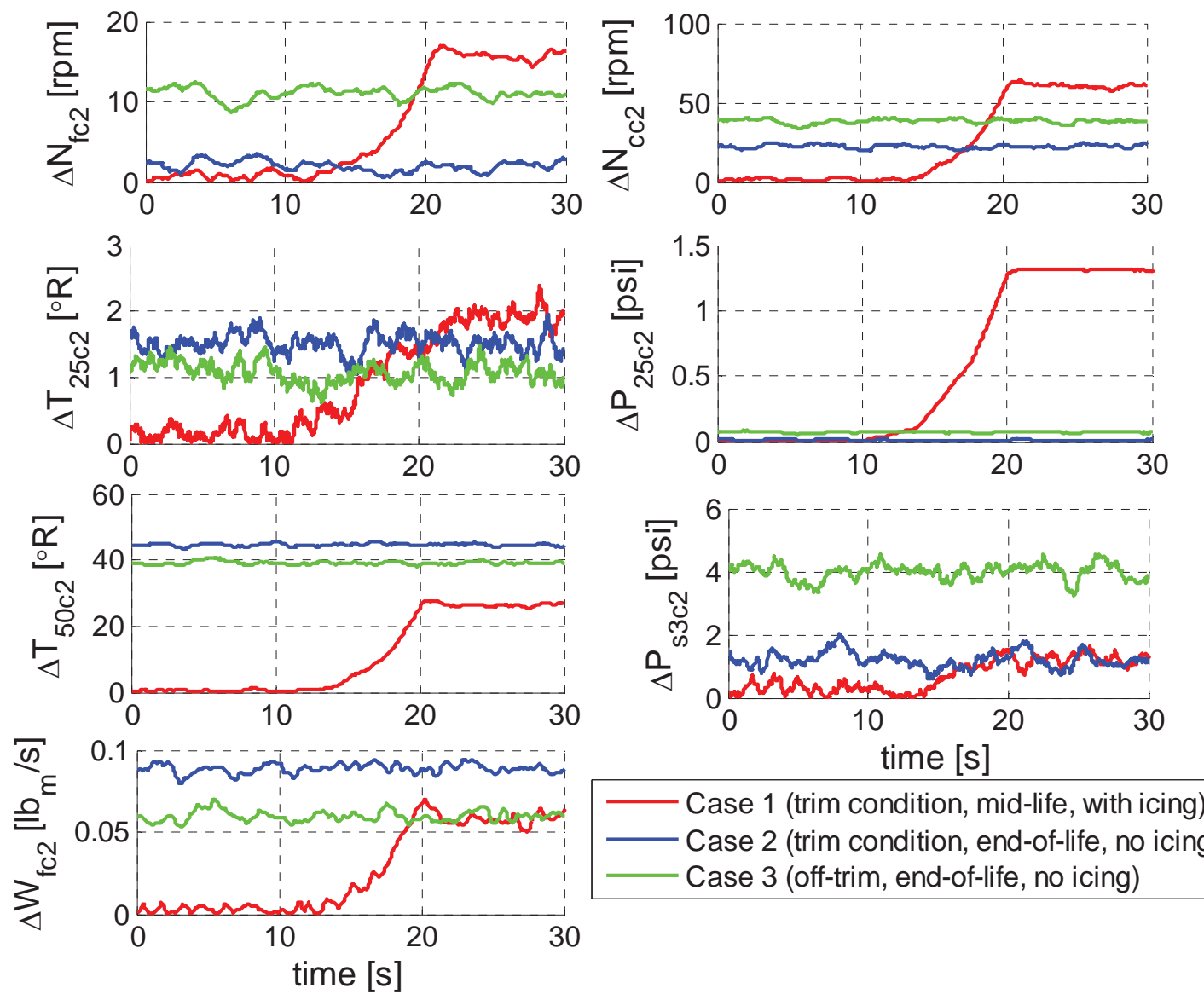

- Case 2 (trim condition, end-of-life, no icing) Case 3 (off-trim, end-of-life, no icing)

Figure 4.-Engine sensor residuals for three flight cases, corrected to inlet conditions (subscript $c 2$ ). Ice accretion occurs in Case 1 from 0 percent at $10 \mathrm{~s}$ to 27 percent blockage at $20 \mathrm{~s}$. 
The magnitude of the residual for Case 1 at 27 percent blockage is less than or approximately equal to the residuals of the other cases for four of the seven sensors. The only sensors that allow for the icing to be distinguished from the other non-iced cases are the fan speed, core speed, and station 25 pressure sensor. Further complicating matters is the fact that the two shaft speed residuals from Case 1 do not exceed the residuals of Case 3 until approximately 19 s (equivalent to 24 percent blockage). Any additional deviation from the trim point condition would likely further reduce the usefulness of these two sensors for ice accretion detection. This leaves us with only the $P_{25}$ sensor to utilize, which again, is not included in every engine. Further, any detection scheme based solely on a single sensor is not robust to sensor failure. Thus another scheme must be developed.

\section{A Practical Detection Scheme}

To overcome the challenges of the residual based approach while still achieving the goals of simple design and low computational overhead, a heuristic-based detection scheme is developed. One of the results of the data plotted in Figure 3 is that there is a clear signature associated with the accretion of ice in the LPC. Regardless of the control scheme, there is a clear rise in the core shaft speed $\left(N_{c}\right)$ and the exhaust gas temperature $\left(T_{50}\right)$. When EPR is controlled, there is an additional increase in the fuel flow rate $\left(W_{f}\right)$ and fan speed $\left(N_{f}\right)$. When under fan speed control, there is a slight decrease in the core pressures $\left(P_{s 3}\right.$ and $P_{50}$ ). If the station 25 sensors are present then there is an additional indication as the value of both pressure and temperature at station 25 decreases (directly due to the change in the LPC map). The case where the station 25 sensors are not present poses a particular challenge due to that fact that the icing signature is not unique. In fact, any increase in fuel flow rate will result in an increase in core shaft speed, fan shaft speed (when EPR controlled), and exhaust gas temperature. However, if the inputs to the engine are relatively constant then we should still be able to detect this increase in engine operating point.

These observations constitute the fault signature and can be used to develop a detection heuristic. Note that this detection approach only works when the engine input conditions are near steady-state (relatively constant $P_{2}, T_{2}$, and PLA). This limitation should not be overly burdensome as nearly all cases of expected engine icing have occurred during cruise or descent where the flight condition is very slowly changing and the engine throttle is constant.

Detection of this icing signature then consists of determining when the appropriate sensor outputs are changing. To do this, once the engine input parameters are in quasi-steady-state (Ref. 12) a long horizon moving average is computed for each of the variables of interest in addition to a much shorter horizon filter (or simply the already available conditioned signal). For sensor measurements that increase during icing, we look for when the lightly filtered signal is greater than the heavily filtered signal and the reverse for decreasing sensors. When all of the sensors have the proper condition, a counter is incremented for each consecutive control time step for which the true condition exists. If any of the conditions become false, then the counter is reset. Once this counter exceeds a threshold value, the ice accretion is declared as occurring. This procedure is shown as a flow chart in Figure 5 where the input "sensor values" is the vector of all the sensors used for detection.

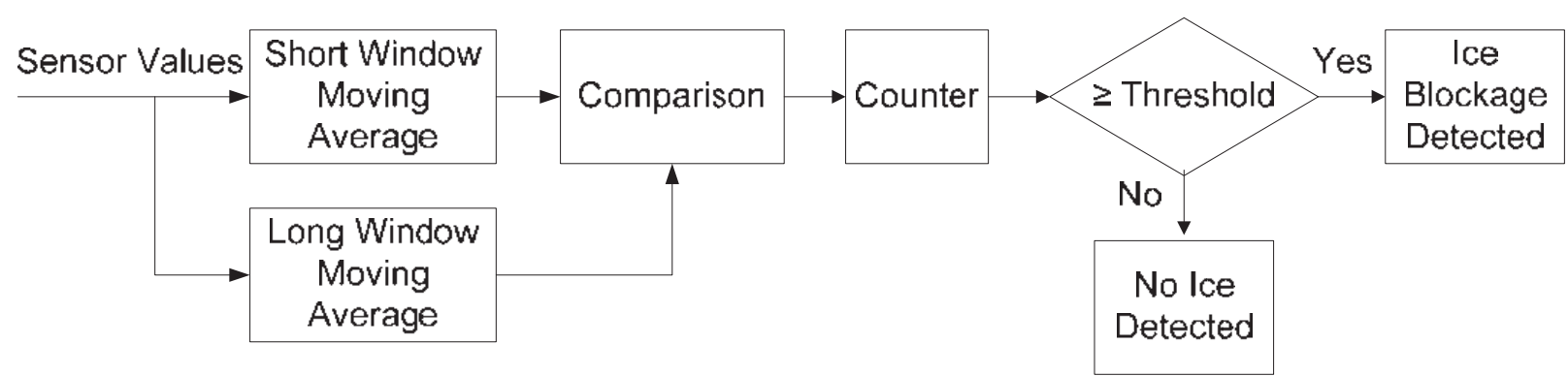

Figure 5.-Flow chart depicting the ice blockage detection scheme. The counter block will reset to zero when a "false" value is received. 
To determine the value of the threshold, a series of steady-state, non-iced simulations are conducted. The inputs to these simulations are chosen randomly around the flight envelope with sensor noise, random engine deterioration, and engine-to-engine variation (Ref. 13) providing variability. The output of these Monte-Carlo tests is then run through the detection scheme to determine what threshold value will result in the desired false positive rate.

\section{Results}

The results presented in this section are for an EPR controlled engine and for linear ice growth from 0 to 27 percent blockage over $120 \mathrm{~s}$. As more information on the physical ice accretion process becomes available this can be modified to generate more realistic results. From a detection standpoint, it would require modifying the length of the moving average filters, but not the basic structure. For the purposes of this paper, the time horizon is fixed at $1.5 \mathrm{~s}$ for the fast filter. The window size of the long moving average is tested at 60,90, and 120 s to determine the impact on detection speed and accuracy. These values are relatively arbitrary with the primary consideration being to minimize the additional delay in detection time due to the faster filter. The other consideration is that the effects of the ice accretion should not significantly impact the long average. It is expected that the long filter's horizon and the ice accretion time (to some fixed "undesirable" value) will be of similar magnitude.

Four cases are considered: without and with station 25 sensors, and desired false positive rates of 1 and 0.1 percent.

\section{A. Without Station 25 Sensors}

When operating an engine without station 25 sensors, the detection algorithm looks for cases where the outputs of four sensors $\left(N_{f c 2}, N_{c c 2}, T_{50 c 2}\right.$, and $\left.W_{f c 2}\right)$ are increasing. Running this algorithm with a $60 \mathrm{~s}$ window on the 5,000 non-iced simulations results in maximum counter values (cases when all conditions are true) as shown in Figure 6. The long tail means that the detection threshold will have to be quite high to get the desired false positive rates. In fact, the threshold values are 1387 and 1032 for 0.1 and 1 percent false positive rates, respectively. Note that the time step of the simulation is $15 \mathrm{~ms}$, thus these detection thresholds are equivalent to 20.81 and 15.48 s, respectively.

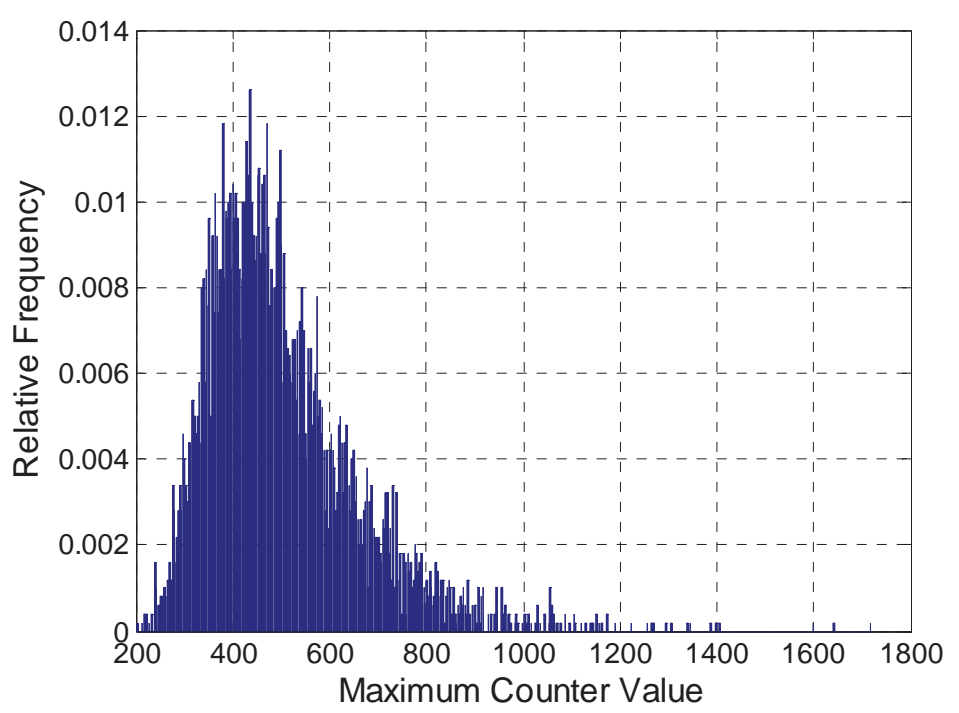

Figure 6.-Histogram of maximum counter values for 5000 un-iced simulations using a $60 \mathrm{~s}$ moving average window for detection without station 25 sensors. Relative frequency is the number of occurrences divided by the total number of test cases. 
To evaluate the performance of the detection scheme, 5,000 more simulations (steady-state operation with variability due to operating point, sensor noise, engine age, and engine-to-engine variation) are conducted all with ice accreting from 0 to 27 percent between time 120 and $240 \mathrm{~s}$. The histogram of when detection occurs is shown in Figure 7 for both threshold values. Not surprisingly, the detection typically occurs sooner for the case tuned to have a 1.0 percent false positive rate. However, both cases show surprisingly good true positive detection rates (97.58 and 98.04 percent for the 1 percent false positive and 0.1 percent false positive cases, respectively). Also, it is interesting to note that there are rare cases where the presence of icing is detected extremely early (e.g., $2.17 \mathrm{~s}$ after initiation or 0.488 percent blockage). This is simply due to the random nature of the sensor noise meeting the conditions prior to the onset of icing.

The same process described above is repeated for windows of 90 and $120 \mathrm{~s}$ to determine the impact of that parameter on detection accuracy and speed. The results (and those for the $60 \mathrm{~s}$ window) are summarized in Tables 1 and 2. From this we observe that the choice of window length has minimal impact on the detection capabilities as long as the window is "long enough." From the data here, the window could be chosen at 50 percent of the time to "unsafe" ice level and still achieve satisfactory results.
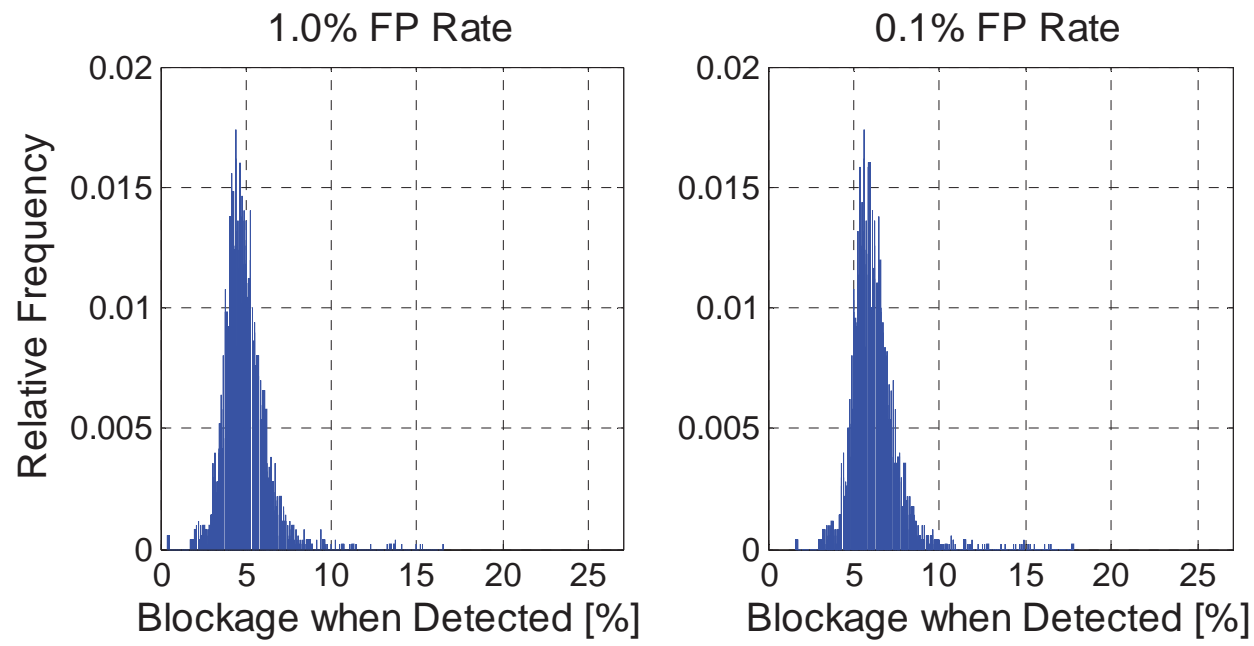

Figure 7.-Histogram of percent blockage when ice accretion is detected using a $60 \mathrm{~s}$ moving average window when tuned to achieve a 1 percent false positive (FP) rate and a 0.1 percent false positive rate, when station 25 sensors are not available.

TABLE 1.-SUMMARY OF ICE ACCRETION DETECTION RESULTS FOR THREE WINDOW LENGTHS TUNED TO ACHIEVE 1.0 PERCENT FALSE POSITIVE RATE, NOT USING THE STATION 25 SENSORS

\begin{tabular}{|c|c|c|c|c|c|}
\hline \multicolumn{6}{|c|}{ 1.0\% False Positive Rate } \\
\hline \multirow{2}{*}{$\begin{array}{l}\text { Window } \\
\text { length }\end{array}$} & \multirow{2}{*}{$\begin{array}{c}\text { Threshold } \\
\text { value }\end{array}$} & \multirow{2}{*}{$\begin{array}{l}\text { True positive } \\
\text { rate }\end{array}$} & \multicolumn{3}{|c|}{ Blockage when detected } \\
\hline & & & Mean & $\begin{array}{l}\text { Standard } \\
\text { deviation }\end{array}$ & Median \\
\hline $60 \mathrm{~s}$ & 1032 & $97.58 \%$ & $4.896 \%$ & $1.166 \%$ & $4.770 \%$ \\
\hline $90 \mathrm{~s}$ & 1027 & $97.96 \%$ & $4.822 \%$ & $1.128 \%$ & $4.703 \%$ \\
\hline $120 \mathrm{~s}$ & 990 & $98.14 \%$ & $4.703 \%$ & $1.058 \%$ & $4.561 \%$ \\
\hline
\end{tabular}

TABLE 2.-SUMMARY OF ICE ACCRETION DETECTION RESULTS FOR THREE WINDOW LENGTHS TUNED TO ACHIEVE 0.1 PERCENT FALSE POSITIVE RATE, NOT USING THE STATION 25 SENSORS

\begin{tabular}{|c|c|c|c|c|c|}
\hline \multicolumn{6}{|c|}{$0.1 \%$ False Positive Rate } \\
\hline \multirow{2}{*}{$\begin{array}{c}\text { Window } \\
\text { length }\end{array}$} & \multirow{2}{*}{$\begin{array}{c}\text { Threshold } \\
\text { value }\end{array}$} & $\begin{array}{c}\text { True positive } \\
\text { rate }\end{array}$ & & \multicolumn{3}{|c|}{ Blockage when detected } \\
\cline { 4 - 6 } & & $98.04 \%$ & $6.131 \%$ & $1.229 \%$ & $5.981 \%$ \\
\hline $60 \mathrm{~s}$ & 1387 & $98.06 \%$ & $5.976 \%$ & $1.161 \%$ & $5.846 \%$ \\
\hline $90 \mathrm{~s}$ & 1363 & $98.10 \%$ & $5.895 \%$ & $1.087 \%$ & $5.738 \%$ \\
\hline $120 \mathrm{~s}$ & 1338 & \multicolumn{3}{|c}{} \\
\hline
\end{tabular}




\section{B. With Station 25 Sensors}

When the station 25 pressure and temperature sensors are available, the ice accretion fault signature should be much easier to identify. This is due to the fact than an increase in the fuel flow rate will generally cause an increase in both station 25 sensor outputs, however when icing is present we observe that both outputs decrease. Thus the detection algorithm looks for a period of time where there is an increase in the outputs of the $N_{f c 2}, N_{c c 2}, T_{50 c 2}$, and $W_{f c 2}$ sensors and a simultaneous decrease in the outputs of the $T_{25 c 2}$ and $P_{25 c 2}$ sensors. Again, the long and short window filters are used to process the sensor outputs prior to determining if the signature is present. This algorithm is then run on the 5,000 un-iced simulations to determine the threshold that will result in the desired false positive rate.

The histogram of the un-iced results is shown in Figure 8 when a $60 \mathrm{~s}$ window is used. Immediately we observe that the distribution is much tighter and closer to zero than that shown in Figure 6, even with the presence of a very long tail on the right hand side. By analyzing the data we find that to achieve a false positive rate of 1 percent, a threshold of 547 iterations must be used, and for 0.1 percent the threshold is 741. Again, this shows that the icing signature is much more distinguishable when the station 25 sensors are available to use.

When the detection algorithm with a 60 s moving average window is run on the 5,000 Monte Carlo cases where ice accretion occurs from 120 to 240 s the detection time histograms shown in Figure 9 are achieved. When the threshold is selected to achieve a 1 percent false positive rate, the average time of detection is $21.6 \mathrm{~s}$ after initiation of ice accretion, which is equivalent to 4.86 percent ice blockage. With the 0.1 percent false positive rate, the average time of detection increases slightly to $26.6 \mathrm{~s}$ after initiation or 5.99 percent ice blockage. Further, the true positive rates are 97.06 and 97.24 percent for 1 and 0.1 percent false positive rates, respectively.

As before, the tests were repeated using windows of 90 and $120 \mathrm{~s}$ for the long moving average filter. The results for both 1.0 percent false positive rate and 0.1 percent false positive rates are shown in Tables 3 and 4, respectively. Again, the impact of increasing the window length is relatively small, resulting in only minor improvements in true positive rate and percent blockage before ice accretion detection.

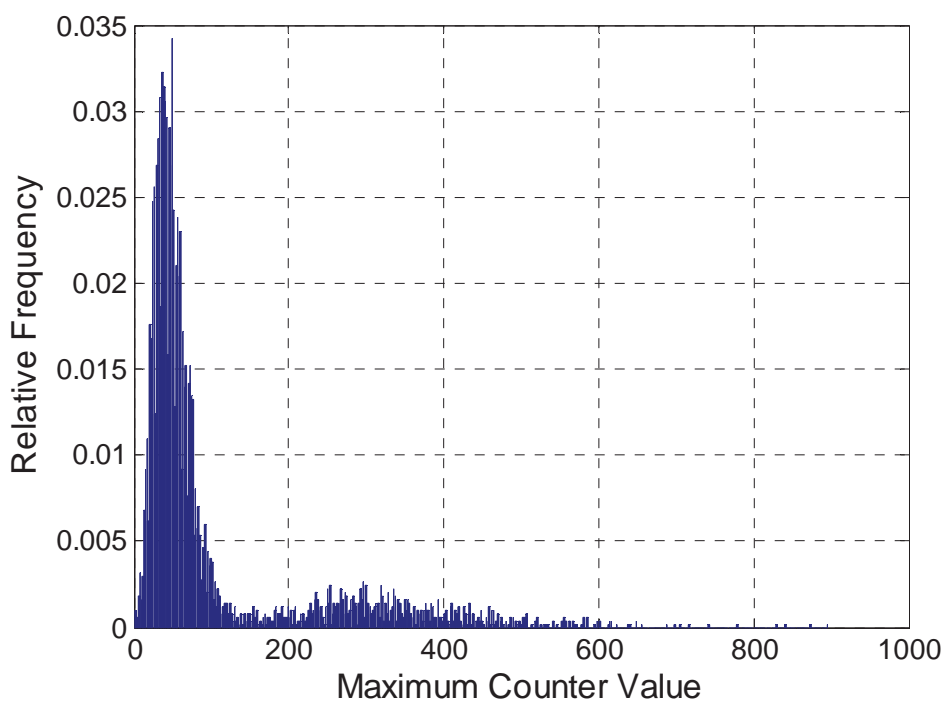

Figure 8.-Histogram of maximum counter values for 5000 un-iced simulations using a $60 \mathrm{~s}$ moving average window for detection with station 25 sensors. 
1.0\% FP Rate

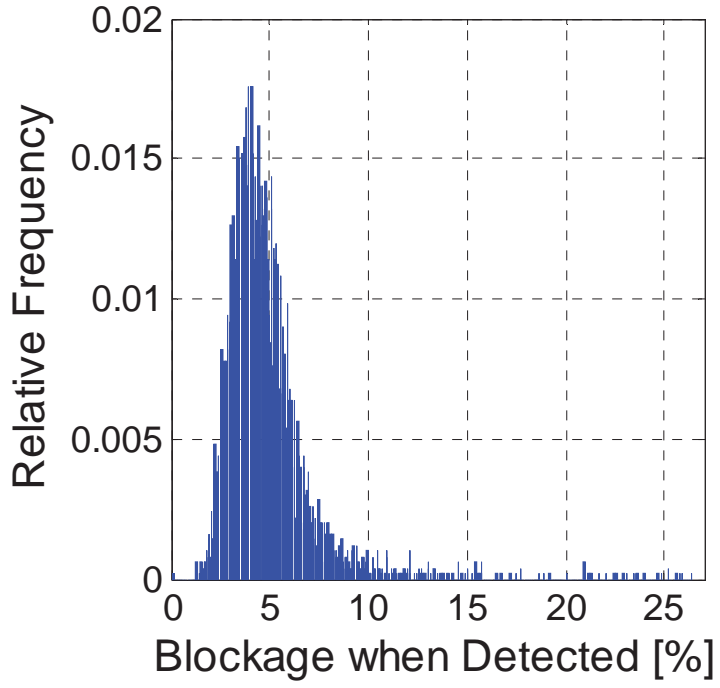

$0.1 \%$ FP Rate

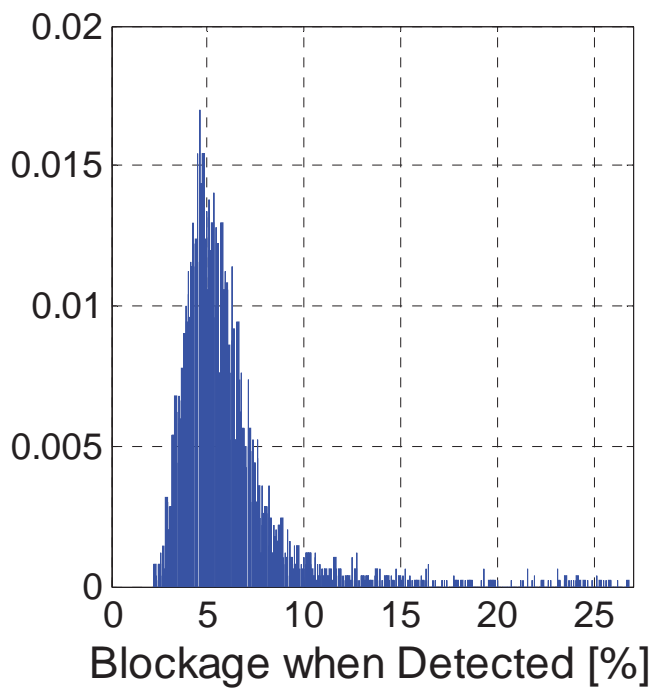

Figure 9.-Histogram of percent blockage when ice accretion is detected using a $60 \mathrm{~s}$ moving average window when tuned to achieve a 1 percent false positive (FP) rate and a 0.1 percent false positive rate, when station 25 sensors are used.

TABLE 3.-SUMMARY OF ICE ACCRETION DETECTION RESULTS FOR THREE WINDOW LENGTHS TUNED TO ACHIEVE 1.0 PERCENT FALSE POSITIVE RATE USING THE STATION 25 SENSORS

\begin{tabular}{|c|c|c|c|c|c|}
\hline \multicolumn{6}{|c|}{$1.0 \%$ False Positive Rate } \\
\hline \multirow{2}{*}{$\begin{array}{c}\text { Window } \\
\text { length }\end{array}$} & \multirow{2}{*}{$\begin{array}{c}\text { Threshold } \\
\text { value }\end{array}$} & \multirow{2}{*}{$\begin{array}{c}\text { True positive } \\
\text { rate }\end{array}$} & & \multicolumn{3}{|c|}{ Blockage when detected } \\
\cline { 4 - 6 } & & $97.06 \%$ & $4.868 \%$ & $2.374 \%$ & $4.408 \%$ \\
\hline $60 \mathrm{~s}$ & 547 & $97.64 \%$ & $4.653 \%$ & $2.219 \%$ & $4.217 \%$ \\
\hline $90 \mathrm{~s}$ & 530 & $98.46 \%$ & $4.489 \%$ & $2.062 \%$ & $4.095 \%$ \\
\hline $120 \mathrm{~s}$ & 510 & \multicolumn{3}{|c|}{} & \\
\hline
\end{tabular}

TABLE 4.-SUMMARY OF ICE ACCRETION DETECTION RESULTS FOR THREE WINDOW LENGTHS TUNED TO ACHIEVE 0.1 PERCENT FALSE POSITIVE RATE USING THE STATION 25 SENSORS

\begin{tabular}{|c|c|c|c|c|c|}
\hline \multicolumn{6}{|c|}{ 0.1\% False Positive Rate } \\
\hline \multirow{2}{*}{$\begin{array}{l}\text { Window } \\
\text { length }\end{array}$} & \multirow{2}{*}{$\begin{array}{l}\text { Threshold } \\
\text { value }\end{array}$} & \multirow{2}{*}{$\begin{array}{l}\text { True positive } \\
\text { rate }\end{array}$} & \multicolumn{3}{|c|}{ Blockage when detected } \\
\hline & & & Mean & $\begin{array}{l}\text { Standard } \\
\text { deviation }\end{array}$ & Median \\
\hline $60 \mathrm{~s}$ & 741 & $97.24 \%$ & $5.981 \%$ & $2.838 \%$ & $5.357 \%$ \\
\hline $90 \mathrm{~s}$ & 698 & $97.66 \%$ & $5.589 \%$ & $2.622 \%$ & $5.033 \%$ \\
\hline $120 \mathrm{~s}$ & 694 & $97.94 \%$ & $5.519 \%$ & $2.530 \%$ & $4.973 \%$ \\
\hline
\end{tabular}




\section{Summary}

The true positive rates for all twelve configurations tested are relatively consistent between 97 and 98 percent. As expected, requiring a lower rate of false positives increases the detection time. Most interestingly though, the results of the detection algorithm are quite similar regardless of whether the station 25 sensors are used. Ice accretion is detected with slightly lower blockage when the station 25 sensors are included (as shown in Table 5), but it is not as large as one would expect given the differences in the threshold values.

TABLE 5.-MEDIAN ICE BLOCKAGE LEVEL AT DETECTION FOR THE FOUR CONFIGURATIONS TESTED USING A WINDOW OF $60 \mathrm{~S}$

\begin{tabular}{|c|c|c|}
\hline False positive rate & Without station 25 sensors & With station 25 sensors \\
\hline $1.0 \%$ & $4.770 \%$ & $4.408 \%$ \\
\hline $0.1 \%$ & $5.981 \%$ & $5.357 \%$ \\
\hline
\end{tabular}

While a false positive rate of 1 or even 0.1 percent is not necessarily acceptable for in-flight use, these rates could be further reduced by the addition of a HIWC detector device. Since it is currently believed that the HIWC condition is necessary for ice particle accretion in the engine core, a "true" output from a HIWC detector could be added to the detection scheme that would dramatically reduce the false positive rate while not impacting the detection capability of the engine sensor based approach.

It is important to recognize that these fault signatures are not found only in cases of engine ice accretion. Other faults, such as stuck fuel metering valves, can manifest with similar signature. When the station 25 sensors are added to the detection scheme it becomes more discriminating, however a variety of LPC faults can produce the same trends. Direct estimation of the changes in the LPC map due to ice accretion requires a more complicated detection. Again, the addition of an HIWC sensor would improve the specificity of the detection algorithm.

\section{Conclusion}

A simple algorithm for the detection of ice particle accretion in the engine low pressure compressor has been developed. This approach uses the typically existing engine sensor suite and is computationally simple in order to enable rapid implementation on modern aircraft engines. Two approaches were studied, one with and one without the presence of the station 25 pressure and temperature sensors. Both approaches had similar results in regard to true positive detection rates, while there is a slight advantage in detection time when using the station 25 sensors. Regardless of approach, the detection algorithm would benefit greatly from the addition of a high ice water content sensor. This sensor would allow for significant improvements in false positive rates while not impairing the detection capability.

Much work remains to be done in this area. The ice accretion models need to be validated once sufficient data are gathered. The overall engine system performance also needs to be validated once experimental data are available. Further work on developing more complex detection schemes may also be beneficial for improving detection and reducing the detection latency. Finally, work on developing mitigation strategies needs to be done to determine what course of action can and should be taken to enable the engines to continue to operate and produce thrust safely. 


\section{References}

1. Mason, J., and Strapp, W., "Current Perspectives on Jet Engine Power Loss in Ice Crystal Conditions: Engine Icing,” Presentation at 2008 AIAA Atmospheric and Space Environments, June 23rd, 2009.

2. Mason, J.G., Strapp, J.W., Chow, P., “The Ice Particle Threat to Engines in Flight,” AIAA 2006206, 44 ${ }^{\text {th }}$ AIAA Aerospace Sciences Meeting and Exhibit, Jan 9-12, 2006.

3. Lawson, R.P., Angus L.J., and Heymsfield A.J., "Cloud Particle Measurements in Thunderstorm Anvils and Possible Threat to Aviation,” Journal of Aircraft, Vol. 35, No. 1, 1998, pp. 113-121.

4. Davison, C., Ratvasky, T., and Lilie, L., "Naturally Aspirating Isokinetic Total Water Content Probe: Wind Tunnel Test Results and Design Modifications," SAE Technical Paper 2011-38-0036, 2011, doi:10.4271/2011-38-0036.

5. May, R.D., Guo, T-H., Veres J.P., Jorgenson, P.C.E., "Engine Icing Modeling and Simulation (Part 2): Performance Simulation of Engine Rollback Phenomena,” 2011-38-0026, SAE International Conference on Aircraft and Engine Icing and Ground Deicing, Chicago, IL, Jun 13-17, 2011. doi:10.4271/2011-38-0026

6. Mason, J., “Engine Power Loss in Ice Crystal Conditions,” AERO Quarterly, Boeing, Quarter 4, 2007.

7. Jorgenson, P.C.E., Veres, J.P., May, R.D., Wright, W.B., "Engine Icing Modeling and Simulation (Part I): Ice Crystal Accretion on Compression System Components and Modeling its Effects on Engine Performance,” 2011-38-0025, SAE International Conference on Aircraft and Engine Icing and Ground Deicing, Chicago, IL, Jun 13-17, 2011. doi:10.4271/2011-38-0025.

8. May, R.D., Csank, J., Lavelle, T.M., Litt, J.S., and Guo, T.H., “A High-Fidelity Simulation of a Generic Commercial Aircraft Engine and Controller,” AIAA-2010-6630, 2010 AIAA Joint Propulsion Conference, Nashville, TN, July, 2010.

9. Csank, J., May, R.D., Litt, J.S., Guo, T.H., "Control Design for a Generic Commercial Aircraft Engine,” AIAA-2010-6629, 46th AIAA Joint Propulsion Conference \& Exhibit, Nashville, TN, July, 2010.

10. Jaw, L., and Mattingly, J.D., Aircraft Engine Controls: Design, System Analysis, and Health Monitoring, American Institute of Aeronautics and Astronautics, Inc., VA, 2009.

11. Armstrong, J.B., Simon, D.L., "Implementation of an Integrated On-Board Aircraft Engine Diagnostic Architecture,” AIAA-2011-5859, NASA/TM-2012-217279, 47th AIAA Joint Propulsion Conference and Exhibit, San Diego, California, July 31-August 3, 2011.

12. Simon, D.L., Litt, J.S., "A Data Filter for Identifying Steady-State Operating Points in Engine Flight Data for Condition Monitoring Applications,” NASA/TM-2010-216359, ASME Journal of Engineering for Gas Turbines and Power, July 2011, Volume 133, Issue 7, 071603 (8 pages).

13. Simon, D.L., "Propulsion Diagnostic Method Evaluation Strategy (ProDiMES) User's Guide," NASA/TM-2010-215840, January, 2010. 


\begin{tabular}{|c|c|c|}
\hline \multicolumn{2}{|c|}{ REPORT DOCUMENTATION PAGE } & $\begin{array}{l}\text { Form Approved } \\
\text { OMB No. 0704-0188 }\end{array}$ \\
\hline \multicolumn{3}{|c|}{ 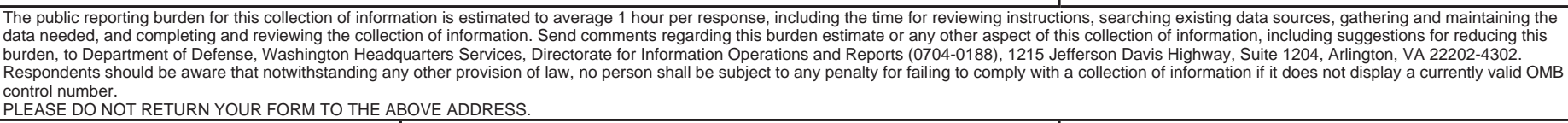 } \\
\hline $\begin{array}{l}\text { 1. REPORT DATE (DD-MM-YYYY) } \\
01-10-2012\end{array}$ & $\begin{array}{l}\text { 2. REPORT TYPE } \\
\text { Technical Memorandum }\end{array}$ & 3. DATES COVERED (From - To) \\
\hline \multirow{3}{*}{\multicolumn{2}{|c|}{$\begin{array}{l}\text { 4. TITLE AND SUBTITLE } \\
\text { Modeling and Detection of Ice Particle Accretion in Aircraft Engin }\end{array}$}} & 5a. CONTRACT NUMBER \\
\hline & & 5b. GRANT NUMBER \\
\hline & & 5c. PROGRAM ELEMENT NUMBER \\
\hline \multirow{3}{*}{\multicolumn{2}{|c|}{$\begin{array}{l}\text { 6. AUTHOR(S) } \\
\text { May, Ryan, D.; Simon, Donald, L.; Guo, Ten-Huei }\end{array}$}} & 5d. PROJECT NUMBER \\
\hline & & 5e. TASK NUMBER \\
\hline & & $\begin{array}{l}\text { 5f. WORK UNIT NUMBER } \\
\text { WBS 284848.02.06.03.02 }\end{array}$ \\
\hline \multicolumn{2}{|c|}{$\begin{array}{l}\text { 7. PERFORMING ORGANIZATION NAME(S) AND ADDRESS(ES) } \\
\text { National Aeronautics and Space Administration } \\
\text { John H. Glenn Research Center at Lewis Field } \\
\text { Cleveland, Ohio 44135-3191 }\end{array}$} & $\begin{array}{l}\text { 8. PERFORMING ORGANIZATION } \\
\text { REPORT NUMBER } \\
\text { E-18487 }\end{array}$ \\
\hline \multirow{2}{*}{\multicolumn{2}{|c|}{$\begin{array}{l}\text { 9. SPONSORING/MONITORING AGENCY NAME(S) AND ADDRESS(ES) } \\
\text { National Aeronautics and Space Administration } \\
\text { Washington, DC 20546-0001 }\end{array}$}} & $\begin{array}{l}\text { 10. SPONSORING/MONITOR'S } \\
\text { ACRONYM(S) } \\
\text { NASA }\end{array}$ \\
\hline & & $\begin{array}{l}\text { 11. SPONSORING/MONITORING } \\
\text { REPORT NUMBER } \\
\text { NASA/TM-2012-217742 }\end{array}$ \\
\hline \multicolumn{3}{|c|}{$\begin{array}{l}\text { 12. DISTRIBUTION/AVAILABILITY STATEMENT } \\
\text { Unclassified-Unlimited } \\
\text { Subject Category: } 07 \\
\text { Available electronically at http://www.sti.nasa.gov } \\
\text { This publication is available from the NASA Center for AeroSpace Information, 443-757-5802 }\end{array}$} \\
\hline
\end{tabular}

\section{SUPPLEMENTARY NOTES}

\section{ABSTRACT}

The accretion of ice particles in the core of commercial aircraft engines has been an ongoing aviation safety challenge. While no accidents have resulted from this phenomenon to date, numerous engine power loss events ranging from uneventful recoveries to forced landings have been recorded. As a first step to enabling mitigation strategies during ice accretion, a detection scheme must be developed that is capable of being implemented on board modern engines. In this paper, a simple detection scheme is developed and tested using a realistic engine simulation with approximate ice accretion models based on data from a compressor design tool. These accretion models are implemented as modified Low Pressure Compressor maps and have the capability to shift engine performance based on a specified level of ice blockage. Based on results from this model, it is possible to detect the accretion of ice in the engine core by observing shifts in the typical sensed engine outputs. Results are presented in which, for a 0.1 percent false positive rate, a true positive detection rate of 98 percent is achieved.

\section{SUBJECT TERMS}

Ice formation; Commercial aircraft; Propulsion system; Engine rollback; Fault detection

\begin{tabular}{|c|c|c|c|c|}
\hline \multicolumn{3}{|c|}{ 16. SECURITY CLASSIFICATION OF: } & \multirow{2}{*}{$\begin{array}{l}\text { 17. LIMITATION OF } \\
\text { ABSTRACT } \\
\text { UU }\end{array}$} & \multirow{2}{*}{$\begin{array}{l}\text { 18. NUMBER } \\
\text { OF } \\
\text { PAGES } \\
20\end{array}$} \\
\hline $\begin{array}{l}\text { a. REPORT } \\
\mathrm{U}\end{array}$ & $\begin{array}{l}\text { b. ABSTRACT } \\
U\end{array}$ & $\begin{array}{l}\text { c. THIS } \\
\text { PAGE } \\
\text { U }\end{array}$ & & \\
\hline
\end{tabular}



